\title{
Impact of Tidal River Management (TRM) for Water Logging: A Geospatial Case Study on Coastal Zone of Bangladesh
}

\author{
Nur Hussain ${ }^{*}$, Md. Hasibul Islam², Farhana Firdaus ${ }^{2}$ \\ ${ }^{1}$ Beijing University of Aeronautics and Astronautics, Beijing, China \\ ${ }^{2}$ Jahangirnagar University, Savar, Dhaka, Bangladesh \\ Email: *nurhussain@buaa.edu.cn, *nurhussain55@gmail.com
}

How to cite this paper: Hussain, N., Islam, Md. H., \& Firdaus, F. (2018). Impact of Tidal River Management (TRM) for Water Logging: A Geospatial Case Study on Coastal Zone of Bangladesh. Journal of Geoscience and Environment Protection, 6, 122-132.

https://doi.org/10.4236/gep.2018.612009

Received: October 29, 2018

Accepted: December 21, 2018

Published: December 24, 2018

Copyright $\odot 2018$ by authors and Scientific Research Publishing Inc. This work is licensed under the Creative Commons Attribution International License (CC BY 4.0).

http://creativecommons.org/licenses/by/4.0/

c)

\begin{abstract}
Bangladesh is a floodplain dominated country. Coastal delta areas of Bangladesh convey multiple impacts of climate change worth-hit. Most of the rivers carry a huge amount of sediment from upstream piedmont area. The river bed rises due to insufficient upstream water supply. Similarly, the deposited sedimentation creates a large number of sandbars inside the river. That's why, water logging and siltation turn into a serious problem in the south-western region of Bangladesh, especially in Satkhira, Khulna and Jessore district. In the middle of September, 2011 the Tidal River Management (TRM) project approved at the study site for four years to develop the water logging problem with basic consideration of silt management. In this circumstance, this study focused on the consequences of the TRM on water logging in the coastal area of Bangladesh. Primary and secondary data have been used. Geospatial analyses have been used following the NDWI in Arc GIS for water logging area detestation using Landsat Enhance Thematic Mapper (ETM) and Landsat Operational land Image (OLI) satellite images. The geo-spatial analysis denoted, about 5090 acres of agricultural land and about 729 acres of homestead land have been water logged during TRM implementation period.
\end{abstract}

\section{Keywords}

Climate Change, Upstream Water Supply, Sediment, Sea Level Rise, Tidal River Management, Water Logging

\section{Introduction}

The south-west coastal region of Bangladesh covering the Districts of Jessore, 
Satkhira, Khulna and Bageraht suffers massive water logging for the last two decades due to insufficient upstream water supply and river bed rising (UNDP, 1989). Heavy rain of monsoon period creates severe water logging in these particular areas. Monsoon floods are beneficial for increasing soil fertility, but more than normal floods and long-term water logging generate agricultural, economical, and structural infrastructural damages (GOB, 2009; FPCO, 1993). The six sub-districts are Tala, Kolaroa and Satkhira-Sadar in Satkhira district; Paikgacha in Khulna district; Monirampur and Keshabpur in Jessore district which are most effected by long time water logging (OXFAM, 2011; FPCO, 1993). This flood plain is the lower part of the Gangetic delta including Kapotakshi, Salta, Hari-Mukteshwari, Buri-Bhadra, Betna and Sholmari River catchment (Brammer, 2012). At a time the Kapotakshi River was connected with the Ganges River. About 150 years ago this area was disconnected from the flow of Mathabhanga River, which was connected to the Ganges River (Rahaman, 2009). As a result the small rivers of the lower part of the Gangetic delta gradually start to set up and in this cause, massive water logging creates. In 1960s, the Government of East Pakistan implemented a project called "Coastal Embankment Project (CEP)", to convert a brackish water zone to fresh water zone, cultivating more crops and water logging solution with funding agencies including USAID (BWDB, 2013; Uttaran, 2013). After super cyclones Sidr (2007) and Aila (2009) struck the water logging that includes more area (ADB, 2007; ADB, 2011). The Government of Bangladesh (GOB) obtained an IDA/credit for Emergency Cyclone Recovery and Restoration Project (ECRRP), 2007 and proceeds from this credit would be used to meet the expenses for the proposed Coastal Embankment Improvement Project Phase-1; CEIP-1 (BWDB, 2013). The Government of Bangladesh (GOB) has taken Tidal River Management (TRM) project to re-establish connection with the Ganges flow, re-link the rivers with each other and increase the bottom of Beel area (Shampa \& Pramanik, 2012). In 2011, Executive Committee of the National Economic Council (ECNEC) approved Tidal River Management (TRM) project to develop water logging problem on Pakhimara Beel at Tala Sub-district of Satkhira district. Permanent water logging has been created by project implementation in the project area during the implementation period. This study has detected water logging variation status before the project implementation and present by using Geo-informatics including remote sensing, GPS and GIS techniques. Furthermore the mid and near infrared bands have strong reflectance by soil and vegetation and absorbance by water, which separates the land and water body to detect the water logging. Landsat Multi-spectral Scanner (MSS) Landsat operational land Image (OLI) imageries useful to detect the water logging area according to normalized difference water index (NDWI) (Gao, 1995). However, the main aim of the study to know the Tidal River Management (TRM) and its impact on water logging using remote sensing based geo-spatial approaches. The specific objectives of the study are given in the following heads; a) to understand the Tidal 
River Management (TRM) project, b) to explore the water logging area with previous condition, and c) to detect the intendant and un-intendant causes of water logging in the study area.

\section{Study Area}

The Pakhimara beel is located between Kapotakshi and Salikha rivers in Magura, Jalalpur and Khesara union in the Tala sub-district of Satkhira District in the south-west coastal part of Bangladesh. 13 mouza are exclusively effected this Beel on 3 Union. More than 13,000 people in 3151 households are directly and indirectly depend on this beel for survival. The Geographic location of the "Pakhimara Beel" is $22^{\circ} 41^{\prime} 41.98^{\prime \prime} \mathrm{N}$ to $22^{\circ} 39^{\prime} 32.19^{\prime \prime} \mathrm{N}$ latitude and $89^{\circ} 13^{\prime} 34.12^{\prime \prime} \mathrm{E}$ to $89^{\circ} 15^{\prime} 18.52^{\prime \prime}$ E longitude and the variation of elevation from river bank to Beel basin is 5.5 meters. The elevation of the Kapotakshi river bank is 8 meters and 2.5 meters is the bottom of the beel basin (Field survey by Garmin GPS). Figure 1 shows the study area map.

\section{Data and Methods}

In this research, objective base systematic approach has been followed. The process has gradually followed step-by-step approaches according to the research purpose. At fast, project elements have been understand by Initial Environmental Examination (IEE) review. Secondly, the water logging area has been detected by using satellite and remote sensing data. To analyze images there have been used same wavelength band combination by using Erdas Imagine 2014 software (Hexagon Geospatial). The geospatial analysis has been detected

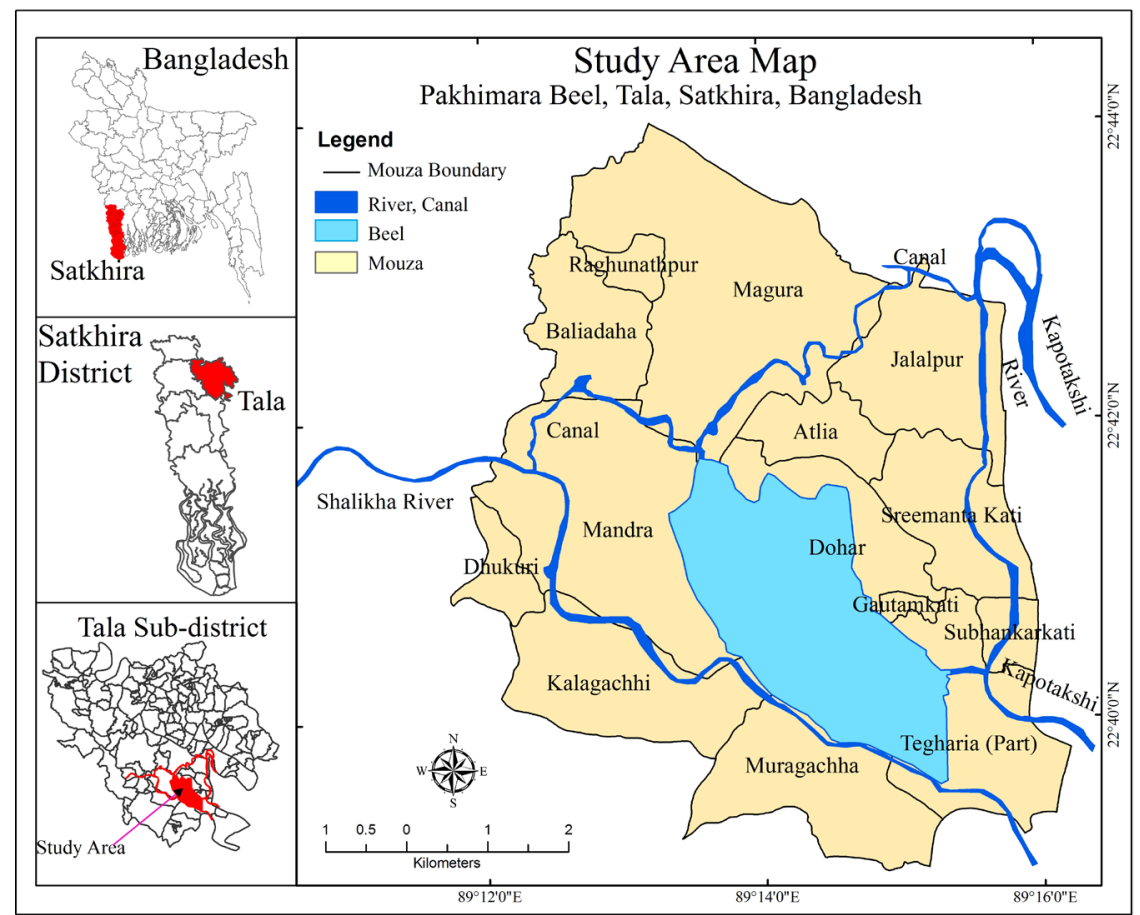

Figure 1. Study area map. 
by using GIS technology Arc Map-10.4 (Esri). Lastly, the detected water logging area has been justified by physical survey with GPS (Garmin GPS) using UTM projection system to track the geo-location and geo-spatial phenomena.

Landsat satellite images (LT51380442000042BKT01, LC81380442016102LGN00) have been used to detect the water logging area (USGS, 2016). The mid and near infrared spectral bands of satellite images have strongly reflected by soil and vegetation and absorbed by water body, which make possible to distinguish the land and water. It can be used to detect the water body (Koponen et al., 2002; Ritchie et al., 2003). Landsat Enhance Thematic Mapper (ETM) imageries have been used for 2000, near infrared band (NIR, Band-4) is effective for water body detection. Landsat Operational land Image (OLI) imageries have been used for 2016, near infrared (NIR, band-5). In addition, The Green band more reflected by water and the NIR infrared band absorb in water body. According to these electromagnetic characteristics, Normalized Difference Water Index (NDWI) has conducted (Gao, 1995). However, NDWI is the most widely used index for remote sensing based water research in past four decades. The NDWI has calculated using following equation;

$$
\text { NDWI }=\frac{(\text { Green band }- \text { NIR band })}{(\text { Green band }+ \text { NIR band })}
$$

where, NDWI is Normalized Deference of Water Index, Green band is the Band 3 of Landsat OLI that $0.53-0.59 \mu \mathrm{m}$ of visible spectrum and NIR band is the band 5 of Landsat OLI that $0.85-0.88 \mu \mathrm{m}$ Near-Infrared spectrum.

\section{Results and Discussion}

On $13^{\text {th }}$ September 2011, Executive Committee of the National Economic Council (ECNEC) has been approved Tidal River Management (TRM) project to develop water logging problem on Pakhimara Beel at Tala Sub-district of Satkhira district. The Tidal River Management (TRM) project of Pakhimara Beel has been approved for four years, but it has not been started on proposed time due to lack of public participation, a local group was taken stay order from the high-court against the Tidal River Management (TRM) project (Uttaran, 2016). Finally the project has been started by the presence of government administrative action. For a successful TRM operation, people's perception and their participation in solving the problems is further needed. Hence, attempt for sustainable solution on a long term basis is felt necessary. Uttaran getting technical and scientific support from CEGIS (Center for Environmental and Geographic Information Services), which has attempted for mitigating this problem and ensuring the participation of the local stakeholders to developing People's Plan for sustainable water management of that area. In this approach, local people identified the catchment wise problems and suggested potential measures for solving them. CEGIS has delineated river catchment area, prepared corresponding maps and conducted Initial Environmental Examination (IEE) on the engineering option finalized by Institute of Water Modeling (IWM) (Uttaran, 2013). 


\subsection{Tidal River Management (TRM)}

The TRM concept has come from local farmers. They make an embankment belonging to the Beel area, during the non-cultivation period, that stores a large volume of high tide water inside of the beels and thus deposits huge sediment in beel basin (Kibria \& Mahmud, 2010). This deposited sediment has been developed soil fertility and increased the elevation of the basin. In this consideration TRM is a system of proper silt management (Alam, 2005). The TRM project has been approved to make cross dam across the river and water divers into the proposed basin (CEGIS, 2007; Paul, 2013). "People's Plan of Action in South-West Coastal Region of Bangladesh" named an Initial Environmental Examination (IEE) have been prepared by Uttaran, Panni committee, Center for Environmental and Geographic Information Services (CEGIS) and Institute of Water Modeling (IWM) (Uttaran, 2013). Figure 2 represent the tidal river management mechanism.

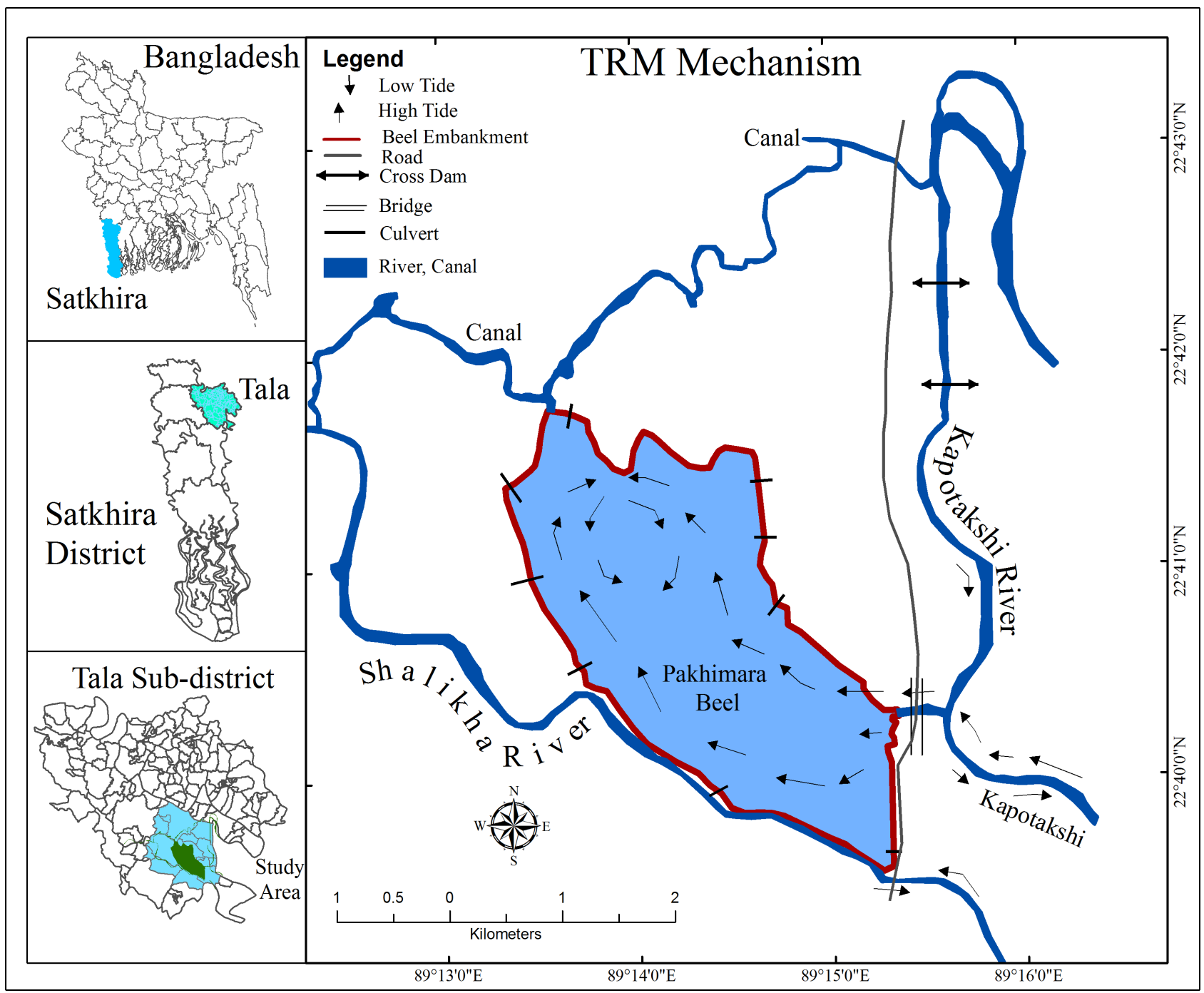

Figure 2. TRM mechanism. 
The four aspects are the basis of the project:

1) Application of the Tidal River Management (TRM) concept;

2) Inter-river linking network;

3) Reviving of dead rivers; and

4) Management of canals and beels inside the polders (Uttaran, 2013; CEGIS, 2006).

The physical changes or land cover and land use changes have been created due to implement of this aspect. The Initial Environmental Examination (IEE) has referred that some changes would be occurred due to implement of this project. All intendant changes included inside of polders. The un-intendant water logging have been occurring with intendant water logging due to the implement of the project in this study area. Figure 3 represents the water logging of study area that was seemed by satellite images.

\subsection{Water Logging}

Water logging has been occurring during the project implementation time. The project has been proposed for water logged in the Beel basin during the project implementation time. The water logging inside of beel basin is intendant water logging which has been proposed by project. The un-intendant water logging have been occurred outside of beel basin. Table 1 shows the land cover of study area for 2000 in acres.

Before the project starting there was not water logging condition and there was 6441 acres of agricultural land in 2016, there 4595 acres have been water

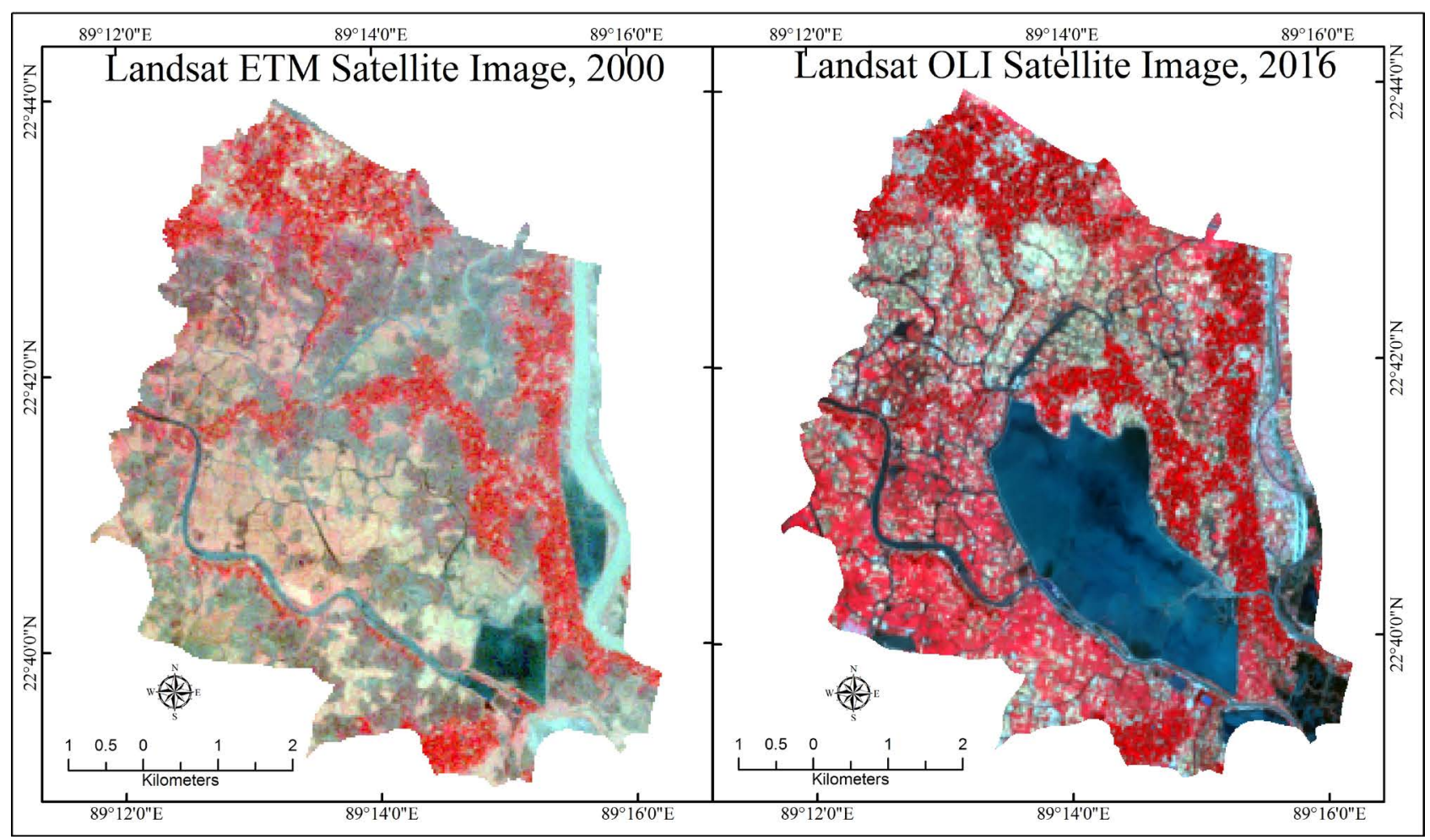

Source: USGS, Compiled by Author: 2016.

Figure 3. Water logging of study area. 
logged. 4903 acres of agricultural land, 778 acres homestead area have been convert into water logging during project time. Table 2 represents land cover of study area of 2016 in acres.

Table 1. Land cover of study area, 2000 (in Acres).

\begin{tabular}{|c|c|c|c|c|c|}
\hline Mouza & Agricultural Land & Homestead & River & Water Body & Grand Total \\
\hline Atlia & 164 & 156 & & & 320 \\
\hline Baliadaha & 440 & 94 & & & 534 \\
\hline Dhukuri & 185 & 0 & & & 185 \\
\hline Dohar & 717 & 308 & 43 & & 1068 \\
\hline Gautamkati & 19 & 31 & & & 50 \\
\hline Jalalpur & 257 & 376 & 103 & & 736 \\
\hline Kalagachhi & 802 & 82 & 63 & & 947 \\
\hline Magura & 892 & 1121 & 43 & & 2056 \\
\hline Mandra & 1497 & 261 & 146 & & 1704 \\
\hline Muragachha & 814 & 192 & 74 & 49 & 1129 \\
\hline Raghunathpur & 59 & 64 & & & 123 \\
\hline Sreemanta Kati & 115 & 268 & 100 & 119 & 602 \\
\hline Subhankarkati & & 2 & 61 & 68 & 132 \\
\hline Tegharia (Part) & 480 & 280 & 143 & 159 & 1062 \\
\hline Grand Total & 6441 & 3235 & 776 & 395 & 10,648 \\
\hline
\end{tabular}

Table 2. Land cover of study area, 2016 (in Acres).

\begin{tabular}{|c|c|c|c|c|c|c|}
\hline Mouza & Agricultural Land & Homestead & River & Water Body & Water Logged & Grand Total \\
\hline Atlia & & 131 & & & 188 & 319 \\
\hline Baliadaha & & 53 & 11 & & 476 & 540 \\
\hline Dhukuri & 13 & & & & 177 & 190 \\
\hline Dohar & 45 & 226 & & 649 & 149 & 1069 \\
\hline Gautamkati & 24 & 23 & & 2 & & 49 \\
\hline Jalalpur & 63 & 250 & 33 & & 354 & 700 \\
\hline Kalagachhi & 385 & 71 & 44 & 44 & 404 & 948 \\
\hline Magura & 273 & 763 & 48 & 3 & 961 & 2048 \\
\hline Mandra & 10 & 355 & 60 & 416 & 1065 & 1906 \\
\hline Muragachha & 406 & 150 & 15 & 304 & 268 & 1143 \\
\hline Raghunathpur & & 17 & & & 106 & 123 \\
\hline Sreemanta Kati & 148 & 193 & 25 & & 136 & 502 \\
\hline Subhankarkati & 57 & & 17 & & & 74 \\
\hline Tegharia & 114 & 225 & 29 & 361 & 308 & 1037 \\
\hline Grand Total & 1538 & 2457 & 282 & 1779 & 4592 & 10,648 \\
\hline
\end{tabular}


Figure 4 denotes the land cover changed during the year of 2000 to 2016. The agricultural land changed and shifted to water logging area. Besides the homestead area also converted to water logging during the project implication time. Figure 5 shows the bar-graph of land cover changing status study area.

\subsection{Intendant and Un-Intendant Water Logging}

This TRM project has been diverted to high tide water in side of Pakhimara beel. As a result, the beel have been started tidal process. In the high tide, the beel have filled up by tidal water with the low land of outside of beel. The riverbank is

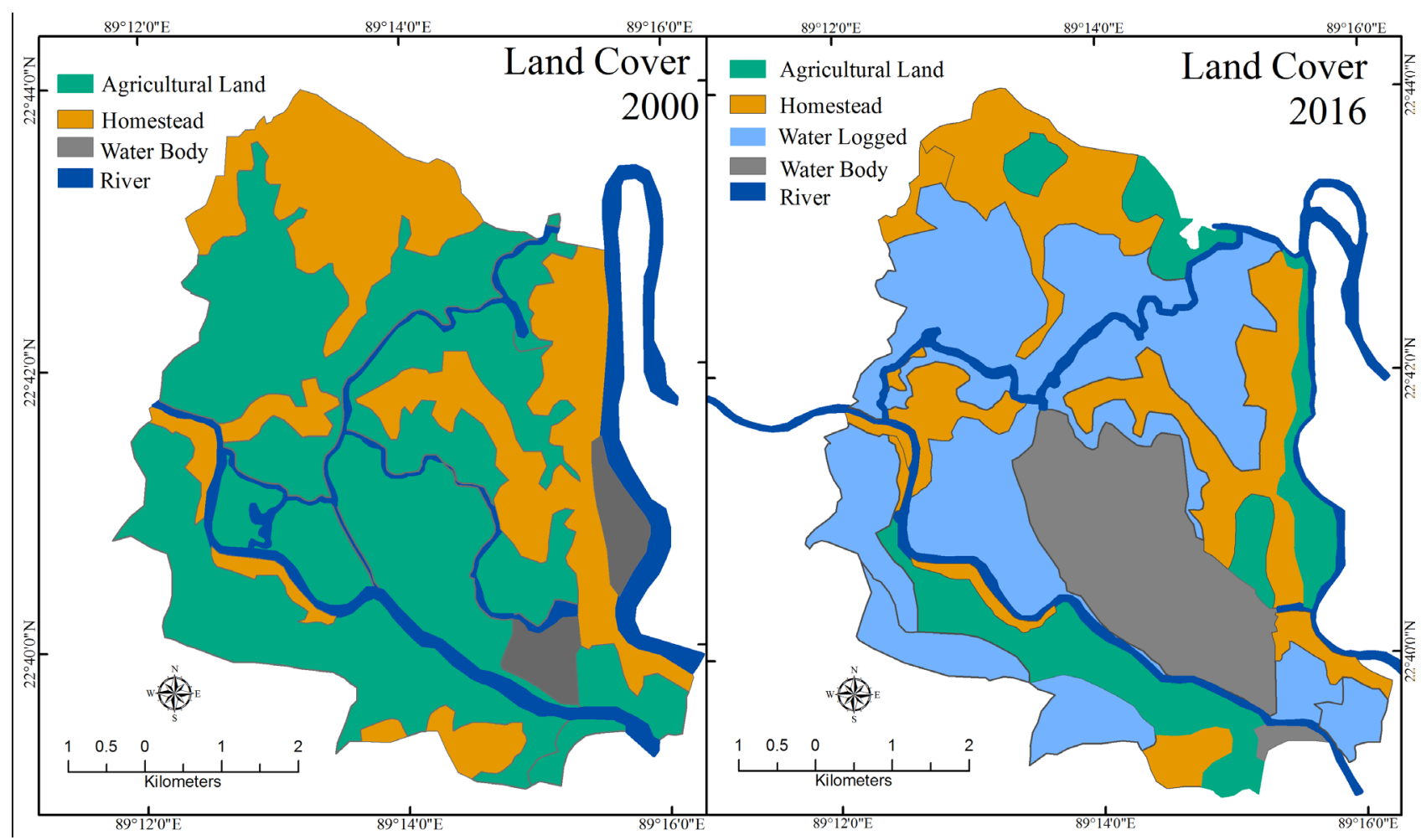

Figure 4. Land cover of the study area.

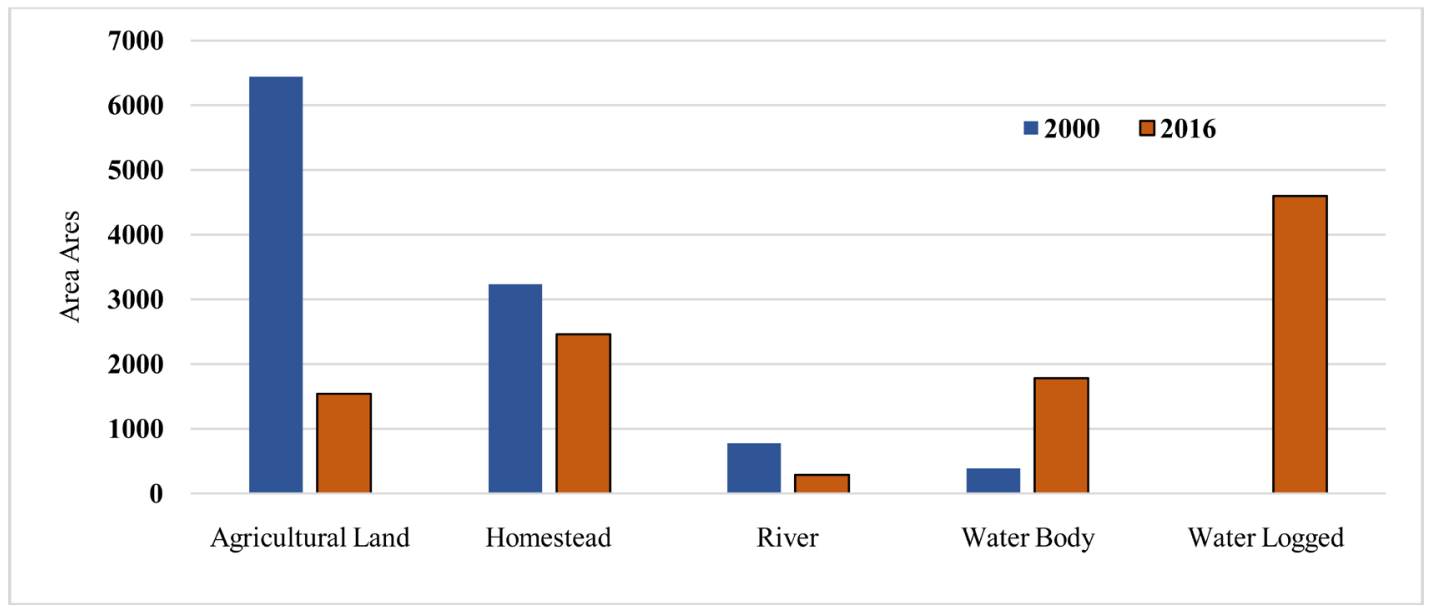

Figure 5. Land cover changes from 2000 to 2016. 
Table 3. Land cover change (in Acres).

\begin{tabular}{ccccc}
\hline Land Cover & 2000 & 2016 & Change & Percentage \\
\hline Agriculture & 6190 & 1760 & -4430 & $-71.5 \%$ \\
Homestead & 3168 & 2126 & -1042 & $-32.8 \%$ \\
River & 895 & 422 & -473 & $-52.8 \%$ \\
Water body with intended logging & 395 & 1780 & 1385 & $350.6 \%$ \\
Water logging & & 4560 & 4560 & \\
Grand Total & $\mathbf{1 0 , 6 4 8}$ & $\mathbf{1 0 , 6 4 8}$ & 0 & 0 \\
\hline
\end{tabular}

higher than catchment area so the tidal water have been occurred the un-intendant water logging in low land. The TMR projected intendant water logging for silt management. However, un-intendant water logging occurred due to insufficiency management. Table 3 shows land cover change (in Acres) during the year of 2000 to 2016.

About 5090 acres of agricultural land have been water logged within 1401 acres of intendant and 3689 acres of un-intendant water logged. Intendant and unintendant both types of water logging have been occurred on homestead area. About 729 acres of homestead land have been water logged during project period. 201 acres of water body have been uncultivable for fishing due to intend and un-intendant water logging.

\section{Conclusion and Recommendation}

Tidal River Management is an important issue on the local people of Pakhimara beel. As the average elevation of Pakhimara beel is just only 2.5 meters, so tide and wave make an impact on water logging. Insufficient upstream water supply and sea level rising also cause the river bed rising. Although the authority of the Tidal River Management project has tried to use the tide and waves of the ocean for making the wetlands to be more sedimented and increase the height, but in the result it is more useless for the local people and creates more waterlogged area which has caused the agricultural and homestead area waterlogged by rising the river bed more than the wetlands. The government although has taken a step to give the affected people some fund for minimizing the effects during the implemented time, but the procedure and the project running are quite questionable. The project runs in the study area only for a short time but the effects of it are remarkable for the local people.

\section{Acknowledgements}

The authors of this research gratefully acknowledge to S. Dara Shamsuddin, Former Professor, Department of Geography and Environment, Jahangirnagar University, Savar, Dhaka-1342, Bangladesh, for behavioral support and supervision. Preciously thankful to Mr. Mizanur Rahman, M.S. Researcher (2017), De- 
partment of Geography and Environment, Jahangirnagar, for supporting to data collection and field observation.

\section{Conflicts of Interest}

The authors declare no conflicts of interest regarding the publication of this paper.

\section{References}

ADB (2007). Khulna-Jessore Drainage Rehabilitation Project, Performance Evaluation Report. Manila: Operations Evaluation Department, Asian Development Bank.

ADB (2011). Adapting to Climate Change Strengthening the Climate Resilience of the Water Sector Infrastructure in Khulna, Bangladesh. Manila: Asian Development Bank.

Alam, A. (2005). River Management in Bangladesh: A People's Initiative to Solve Water-Logging. Khulna: Coastal Development Partnership (CDP).

Brammer, H. (2012). The Physical Geography of Bangladesh. Dhaka: University Press Ltd.

BWDB (2013). EIA Report on Coastal Embankment Improvement Program, Phase 1 (CEIP-I). Dhaka: Ministry of Water Resources, Government of the People's Republic of Bangladesh.

CEGIS (2006). Final Report on Compensation Mechanism for a Tidal Basin during Operation of Tidal River Management (TRM). Dhaka: Bangladesh Water Development Board.

CEGIS (2007). Environmental and Social Impact Assessment of Khulna Jessore Drainage Rehabilitation Project (KJDRP). Final Report. Dhaka: Bangladesh Water Development Board (BWDB).

FPCO (1993). Southwest Area Water Resources Management Project. FAP4 Final Report. Dhaka: Flood Plan Coordination Organization, Bangladesh Ministry of Irrigation, Water Development and Flood Control.

Gao, B. C. (1995). A Normalized Difference Water Index for Remote Sensing of Vegetation Liquid Water from Space. In SPIE's 1995 Symposium on OE, Aerospace Sensing and Dual Use Photonics, Vol. 2480.

GOB (2009). Bangladesh Climate Change Strategy and Action Plan 2009. Dhaka: Ministry of Environment and Forests, Government of the People's Republic of Bangladesh.

Kibria, Z., \& Mahmud, I. (2010). Tidal River Management (TRM): Community Struggle for Indigenous River Management and Climate Change Adaptation in Southwest Coastal Region of Bangladesh, Uttaran, Dhaka, Bangladesh. (Print Only)

Koponen, S., Pulliainen, J., Kallio, K., \& Hallikainen, M. (2002). Lake Water Quality Classification with Airborne Hyperspectral Spectrometer and Simulated MERIS Data. Remote Sensing of Environment, 79, 51-59. https://doi.org/10.1016/S0034-4257(01)00238-3

OXFAM (2011). Monsoon Floods and Water Logging in Bangladesh. Situation Report 01, Dhaka.

Paul, A., Nath, B., \& Rana Abbas, Md. (2013). Tidal River Management (TRM) and Its Implication in Disaster Management: A Geospatial Study on Hari-Teka River Basin Jessore, Bangladesh. International Journal of Geomatics and Geosciences, 4, 125-135.

Rahaman, S. (2009). Assessment of Environmental Degradation to Water-logging and Its Possible Remedial Measures at Kapotaksha Basin Area (KBA). Unpublished MS Thesis, Dhaka: Jahangirnagar University. 
Ritchie, J., Zimba, P., \& Everitt, J. (2003). Remote Sensing Techniques to Assess Water Quality. Photogrammetric Engineering and Remote Sensing, 69, 695-704.

https://doi.org/10.14358/PERS.69.6.695

Shampa, \& Pramanik, I. M. (2012). Tidal River Management (TRM) for Selected Coastal Area of Bangladesh to Mitigate Drainage Congestion. International Journal of Scientific \& Technology Research, 1, 1-6.

UNDP (1989). Bangladesh Flood Policy Study. Final Report. Dhaka: UNDP.

USGS (2016). https://earthexplorer.usgs.gov/

Uttaran (2013). People's Plan of Action in South-West Coastal Region of Bangladesh, Dhaka.

Uttaran (2016). Problem and Solution of Tidal River Management (TRM) Project. 